(C) 1987 ISIJ

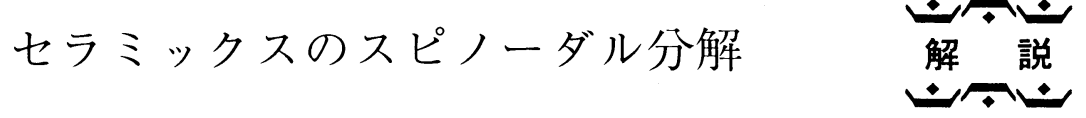

佐久間 健 人 $^{*}$

\title{
Spinodal Decomposition in Ceramic Materials
}

Taketo SAKUMA

\section{1.はじめに}

セラミックスのスピノーダル分解に関する研究は，そ の進展状況が分野によつて大きく異なつている. $\mathrm{SiO}_{2}$ 系ガラスを中心としたガラス、学:の分野では，2 相分離 およびスピノーダル分解の研究は南くから盛んに行われ ており，ガラスの 2 相分離によつて生じた特徴的な組織 の観察結果が，CAHN および HILIERT によるスピノーダ ル分解の理論の形成に対する契機となつたといわれてい る. その後, 多くの系について安定および準安定 2 相分 離が見出されるとともに，相分離が実用上重要な意味を 持つていることが明らかにされた。現在では，ガラスて： 学に携わる研究者, 技術者にとつては, 2 相分離に関す る理解と制御が不叮欠であるといわれている.

一方, 結晶質七ラミックスに関しては, 比較的少数の 系についてスピノーダル分解の基礎的研究がなされてい るにすぎない。これは，スピノーダル分解あるいは 2 相 分離によつて結晶質セラミックスの特性が问上するとい つた実用上の発見がなされていないためであると思われ る、筆者らは最近, $\mathrm{Y}_{2} \mathrm{O}_{3}$ を添加した部分安定化ジルコ ニア (Partially Stabilized Zirconia, PSZ と略称され る）の時効初期段階にスピノーダル分解が起こるらしい ことを報告した，実用化が有望視されているセラミック スのスピノーダル分解ということで, この話題はジルコ ニアセラミックスの研究者の関心を集め, PSZの相分 離が真にスピノーダル分解によつて起こりうるか否かに 関して活発な討論がなされつつある。このような背景を ふまえて, 本稿ではガラス, 結晶質セラミックス, PSZ についてのスピノーダル分解および 2 相分離の研 究の一端を絕介することとする.

\section{2. ガラスの相分離}

多くのけい酸塩は液相状態で 2 相分離を生ずる。けい 酸塩ガラスを融液から冷却すると，層状組織となつたり
乳白色を呈したりすることは古くから知られていたが, これは 2 相分離によつて生じた不均一な微細組織による ことが明らかにされてきている. 1950 年代になつて, 2 相分離によつて生じる特徵的な組織が電子顕微鏡観察 によつて捕えられ，ガラスの微細組織の研究に大きな進 展がもたらされた。 1970 年代にはガラスの相分離に関 する研究の隆盛期を迎え, それに伴つてこの分野の研究 成果がいくつかの解説あるいは集録としてまとめられて いる1) 11).

ガラスには, Fig. 1 に模式的に示したように液相状 態で安定な 2 相分離がある系（a）と，準安定の 2 相分 離を有する系（b）とがある。前者には $\mathrm{SiO}_{2}-\mathrm{BaO}$, $\mathrm{SiO}_{2}-\mathrm{CaO}$ など, 後者には $\mathrm{SiO}_{2}-\mathrm{Na}_{2} \mathrm{O}, \mathrm{SiO}_{2}-\mathrm{Li}_{2} \mathrm{O}$ な どの系がある。これらの系においては，ガラスの結晶化 が起こりにくいために Fig. 1(a) の偏晶温度以下の領域 および Fig. 1(b) の準安定の 2 相分離が起こりやすいと いう特徴を有している。 また， 2 相分離領域の広い系と して安定系で $\mathrm{SiO}_{2}-\mathrm{B}_{2} \mathrm{O}_{3}$, 準安定系で $\mathrm{SiO}_{2}-\mathrm{Al}_{2} \mathrm{O}_{3}$ が よく知られている。一般に, $\mathrm{SiO}_{2}$ と異なつた配位多面 体を構成する網目形成体を含む 2 元系においては広い 2 相分離領域が現れやすいといわれている7). 逆に, 網目 修飾体を含む系では 2 相分離が起こりにくく，2 相分離 領域が存在するにしても $\mathrm{SiO}_{2}$ に富む側の狭い領域に限 られているものが多い.

ガラスの 2 相分離およびスピノーダル分解の研究が盛 んになされてきているのは，ガラス工学の分野において 2 相分離が実用上重要な役割を果たす場合が多いことに よつている。たとえ゙，バイコールガラスの製造工程が 2 相分離を巧みに利用していることはよく知られている 事実である ${ }^{13)}$. バイコールガラスは $\mathrm{SiO}_{2}-\mathrm{B}_{2} \mathrm{O}_{3}-\mathrm{Na}_{2} \mathrm{O}$ が基本系であるが，この系には Fig. 1 (b) のような準安 定の 2 相分離が存在 ( ${ }^{14)}$, しかもこの 2 相分離が起こ りやすいことがこのガラスの製造を容易にしている。 た，鉱石から目的とするセラミックスを抽出する際にも 昭和 62 年 1 月 19 日受付（Received Jan. 19, 1987）（依頼解説）

* 東京大学.学部教授 T博 (Faculty of Engineering, The University of Tokyo, 7-3-1 Hongo Bunkyo-ku, Tokyo 113) Key words : ceramics ; spinodal decomposition ; phase decomposition ; glass ; cermet ; zirconia ; martensitic transformation ; domain structure ; antiphase boundary ; modulated structure. 


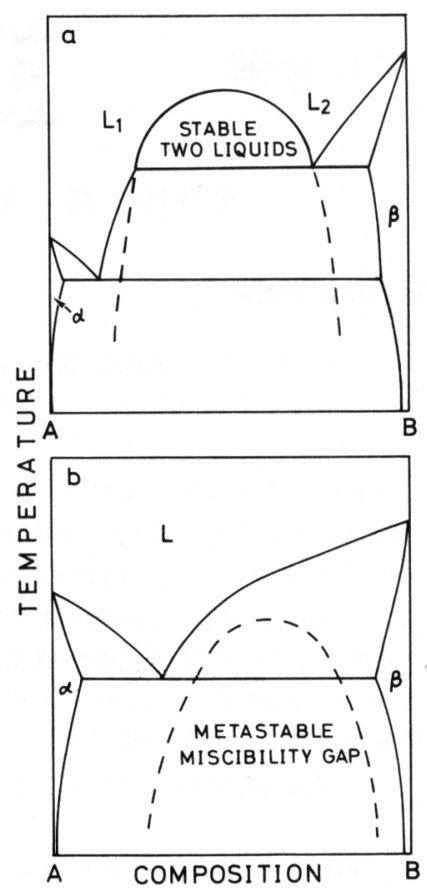

Fig. 1. Two types of phase diagrams with (a) liquid immiscibility and (b) metastable miscibility gap.

2 相分離が利用されている。一例として, ジルコンをアー ク溶解あるいはプラズマ溶解してジルコニアを抽出する 技術があげられる ${ }^{15)}$. ジルコンを溶融後冷却すると, $\mathrm{SiO}_{2}$ に富む相と $\mathrm{ZrO}_{2}$ に富む相に速やかに 2 相分離し， その後これを酸に浸漬して $\mathrm{SiO}_{2}$ に富む相を溶解するこ とによつてジルコニアが抽出される．この 2 相分離は極 めて速やかに進行するので，スピノーダル分解が関与し ているのであろうと考えられている.

このような実用上の重要さとあいまつて，ガラスのス ピノーダル分解に関する基礎的研究も理論的ならびに実 験的に詳細になされている. ガラスのスピノーダル分解 の理論的研究は, 金属材料と同様に $\mathrm{CAHN}^{16)}$ および HILLERT $^{17)}$ の研究に端を発しており, それ以後, より厳 密な解析が多くの研究者によつてなされてきている.こ の理論的解析の進展に関してはすでに文献 8) に詳述さ れているので，ここではガラスのスピノーダル分解の実 験的研究に触れることにする.

この実験手法として最も広く用いられている方法は, 電子顕微鏡による組織観察法とX 線小角散乱法 (SAXS) である. 前者の方法は相分離によつて生じる 微細組織を直接観察できるという大きな利点を有してい る.ガラスを 2 相分離領域で熱処理すると， 2 種類の特 徴的な組織が形成されることが知られている.すなわち, 母相中に孤立した第 2 相粒子が分散している組織と第 2

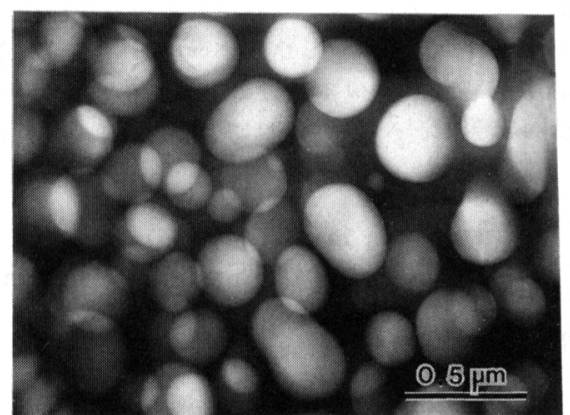

Photo. 1. Microstructure of melted $\mathrm{SiO}_{2}-10$ $\mathrm{mol} \% \mathrm{BaO}$ glass.

相が 3 次元的に連結した組織 (Interconnected structure) とである. Photo. 1 は, $\mathrm{SiO}_{2}-10 \mathrm{~mol} \% \mathrm{BaO}$ の 2 相分離組織であり, 球形の $\mathrm{BaO}$ に富んだ粒子が $\mathrm{SiO}_{2}$ に富む母相中に分布している。この場合には粒子 はかなり密集しているが, それぞれが孤立して存在して おり互いに連結していない. 一方, Interconnected structure では粒子が連結しており，通常の析出組織と は異なつた形態を有している。この形態は, CAHN と CHAVLES がスピノーダル分解理論をもとにコンピュー ターシミュレーションによつて得た組織とよく似てい る ${ }^{18)}$.このため, 以前は Interconnected structure はス ピノーダル分解によつて生じたものであるとされ，組織 の連結の度合から相分離機構を判定できると考えられて いた。しかし，その後の研究により Interconnected structure は核生成, 成長によつても生じるものであり, 第 2 相の体積比が $50 \%$ に近いほど連結しやすいことが 明らかにされた。従つて，現在では組織の形態的な特徵 だけからでは相分離機構を判定できないと理解されてい る.

一方，SAXS 実験は相分離の初期段階に関する情報 を得ることができるので，このデー夕をもとに相分離機 構を明らかにしようという試みが数多くなされている. CAHNの理論によれば，スピノーダル分解においては組 成変動の時間変化が線形微分方程式で記述される “初期 段階”が存在し16)，SAXS のデータには次のような特 徵が現れることになる12).

(1) X 線回折強度 $I(\beta, t)$ と波数 $\beta$ のプロットに は時間 $t$ が変わつても $\beta$ の一定值 $\beta_{m}$ のところに最大值 をもつ.

(2) おのおのの $\beta$ に対する $I(\beta, t)$ の対数值は $t$ と 直線関係を満足する.

( 3 ) $I(\beta, t)-\beta$ プロットには $\beta=\beta_{c}$ で一定の交点が 現れる.ここで $\beta_{c}=\sqrt{2} \beta_{m}$ の関係が成り立つ。

Fig. 2 は, 上記の特徵を模式的に示したものである. ガラスの SAXS 実験は, $\mathrm{PbO}-\mathrm{B}_{2} \mathrm{O}_{3}-\mathrm{Al}_{2} \mathrm{O}_{3}$ および 

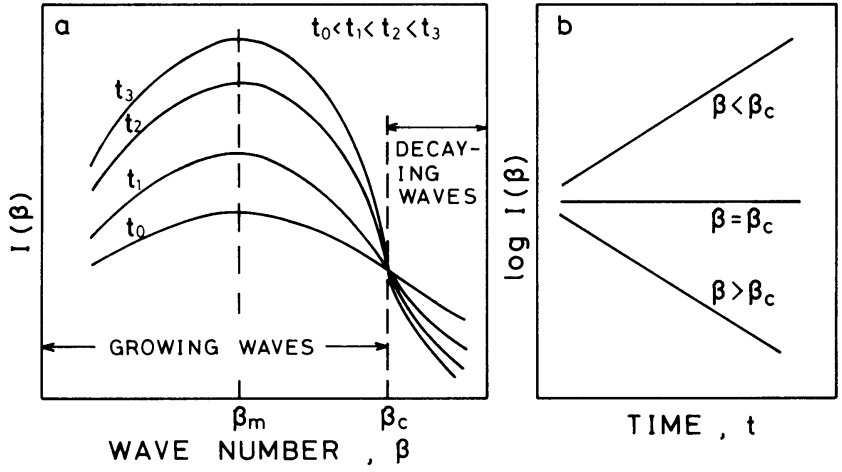

a : $I(\beta)$ vs. $\beta \quad \mathrm{b}: \log I(\beta)$ vs. $t$

Fig. 2. Schematic drawing of small angle X-ray diffraction spectra expected from CaHN's theory of spinodal decomposition.

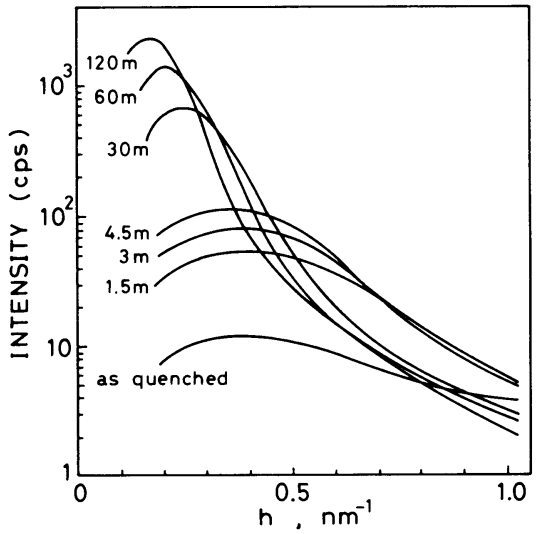

Fig. 3. Small angle $\mathrm{X}$-ray diffraction spectra of a $\mathrm{B}_{2} \mathrm{O}_{3}-19 \mathrm{PbO}-\mathrm{Al}_{2} \mathrm{O}_{3}$ glass quenched from $1150^{\circ} \mathrm{C}$. Heat treatment was made at $450^{\circ} \mathrm{C}$ for various times $^{19)}$.

$\mathrm{Na}_{2} \mathrm{O}-\mathrm{SiO}_{2}$ 系を中心に数多くなされているが, Fig. 3 には一例として $\mathrm{B}_{2} \mathrm{O}_{3}-19 \mathrm{PbO}-5 \mathrm{Al}_{2} \mathrm{O}_{3}$ ガラスのデー夕 を示した ${ }^{19)}$ 。この試料は白金るつぼ中で溶解後, 急速 回転させた鋼製のローラー閏に液相状態で注いで作られ たものである。このようにして急冷された試料のデータ が Fig. 3 に As quenched と印されているものである. 試料はその後 $450^{\circ} \mathrm{C}$ で種々の時临熟処理され, SAXS 実験がなされている。また，网の獚軸 $h$ は散乱べクト ルであり，上述の $\beta$ に対忍するものである．この結果 を Fig. 2 の判定基準と比較してみると次のことが分か る.まず，熱処理の初期段階では $\beta_{m}$ は一定とみなしう るが，時間が経過するとこれが $\beta$ の小さい側にシフト している. 闹様の傾问は $\mathrm{B}_{2} \mathrm{O}_{3}-\mathrm{PbO}-\mathrm{Al}_{2} \mathrm{O}_{3}$ および $\mathrm{Na}_{2} \mathrm{O}-\mathrm{SiO}_{2}$ ガラスについて他の研究者によつても見出 されている2021)。この事尖は，熱処理の初期が CAHN の 理論で記述できるとも解釈できる。 ところが, Fig. 3 のプロファイルは一定の父点が現れていないという点で 理論の予測とは明らかに買なつている。.Fig. 3 はひと

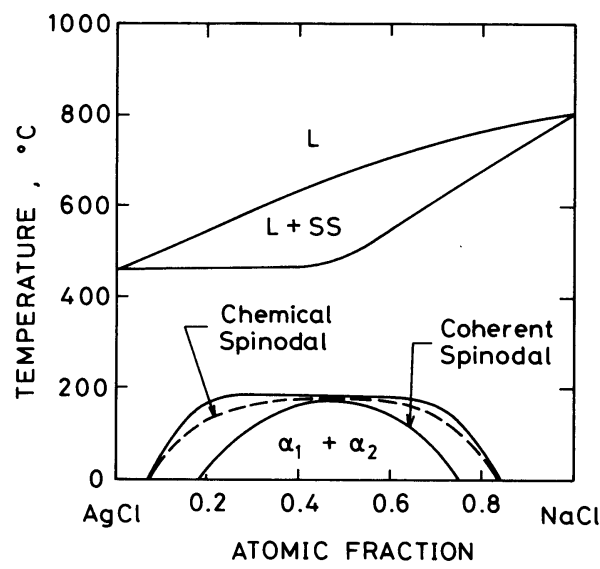

Fig. 4. Phase diagram of $\mathrm{AgCl}-\mathrm{NaCl}$ with the chemical and coherent spinodals calculated by JANTZEN and HeRman ${ }^{11)}$.

つの例を示したにすぎないが，ガラスの SAXS デー夕 には一般にはつきりした交点は観察されず12)，また $\log$ $I(\beta, t)$ と $t$ のプロットも直線性からずれること ${ }^{20)}$ な ど理論と実験との対応は十分とはいえない。この不一致 の原因としては組成の統計的なゆらぎの存在, CAHN 理 論で無視された非線形項の寄与, 初期段階における構造 緩和などが考えられているが，いずれも SAXS データ を分量的に完全に説明できるには至つていない.

\section{3. 結晶質セラミックスのスピノーダル分解}

結晶質セラミックスにも2 相分離型状態図を有する系 は多数存在しこれれの系に拈いてスピノーダル分解が 起こりうることは十分予想されることである.たとえば, $\mathrm{AgCl}-\mathrm{NaCl}$ および $\mathrm{KCl}-\mathrm{NaCl}$ 系は広い 2 相分離領域を 有していることが知られており，これらの系については 化学スピノーダルおよび整合スピノーダル線の計算がな されている．Fig. 4 は $\mathrm{AgCl}-\mathrm{NaCl}$ 系の状態図を示した ものである．眓中に示されている 2 相分離領域は 
STOKES と LIによつて決定されたものであり ${ }^{22)}$, 化学ス ピノーダルおよび整合スピノーダル線の計算結果は JANTZEN と HERMAN $^{11)}$ によるものである. $\mathrm{AgCl}-\mathrm{NaCl}$ 系 はひずみエネルギーが小さくスピノーダル分解が起こり やすいであろうといわれているが11),この系について はいまだスピノーダル分解を示唆する実験的証拠は得ら れていない.

実用上の重要性という意味では炭化物あるいは窒化物 の 2 相分離が興味深い. 各種の炭化物および窒化物系 に2 相分離があることはかなり古くから知られてお $\eta^{23)}$-25), これらの系でもスピノーダル分解が起こりj るものと考えられる. RuDy は， Ti-Mo-C-N 系の TiC に富む領域で 2 相分離が起きることを実験的に見出すと ともに,この系の 2 相分離領域および化学スピノーダル 線を熱力学的計算によつて決定している ${ }^{24)}$. しかし, 彼の計算結果には疑問があり,この系の 2 相分離挙動に 関しては今後のより精細な研究が待たれるところであ る.この種の解析の信頼性はともかくとして, Ti-Mo-C-N 系は最近になつて工具材料としての重要性

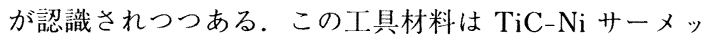
トであり，WC-Co 系超硬合金の代替材料として有望視 されており，すでに実用化がなされているものである. $\mathrm{TiC}-\mathrm{Ni}$ サーメットの特性は, $\mathrm{Mo}_{2} \mathrm{C}$ あるいは $\mathrm{N}$ 添加に よつて向上することが見出され，その実用化が促進され たといわれている26). $\mathrm{Mo}_{2} \mathrm{C}$ あるいは $\mathrm{N}$ 添加は，いずれ も炭化物もしくは炭窒化物粒子を微細にし, $\mathrm{TiC}-\mathrm{Ni}$ 系 サーメットの機械的特性および工具寿命の向上をもたら すことが示されている27)28)。このように, Ti-Mo-C-N 系サーメットの特性向上は粒子の微細化によるものであ り，2 相分離を利用しているわけではないが, この 2 相 分離によつても組織を微細化できることが指摘され,こ れを利用した新しい工具材料の設計に期待がかけられて いる 29 .

結晶質セラミックスにおいてスピノーダル分解の研究 が比較的進んでいるのは酸化物系セラミックスに関して であり，その中でも $\mathrm{SnO}_{2}-\mathrm{TiO}_{2}$ 系に関する研究報告が 多い. $\mathrm{SnO}_{2}$ および $\mathrm{TiO}_{2}$ はいずれもルチル型構造をと り, $\mathrm{SnO}_{2}-\mathrm{TiO}_{2}$ 系は Fig. 5 のような 2 相分離型状態図 を有している ${ }^{30)}$. Fig. 5 に示されている 2 相分離の相 境界線は, 研究者によつて多少の相違はあるもの $の^{30)-32)}$ ，いずれも中央組成に関してほぼ対称な形を有 しており， $1200^{\circ} \mathrm{C}$ 以下の低温領域を除けば単純正則 溶体近似で記述できることが示されている ${ }^{30)}$. PARK ら は, 室温における $\mathrm{TiO}_{2}$ の弾性定数の測定值を用いて, CAHNの理論をもとに整合スピノーダル線を計算してい る $^{30)}$. その計算結果は Fig. 5 に破線で示されている.

$\mathrm{SnO}_{2}-\mathrm{TiO}_{2}$ の弾性的に軟らかい方向は [001] 万向であ り，この方向にスピノーダル分解による濃度変調が生ず るものと考えられる。

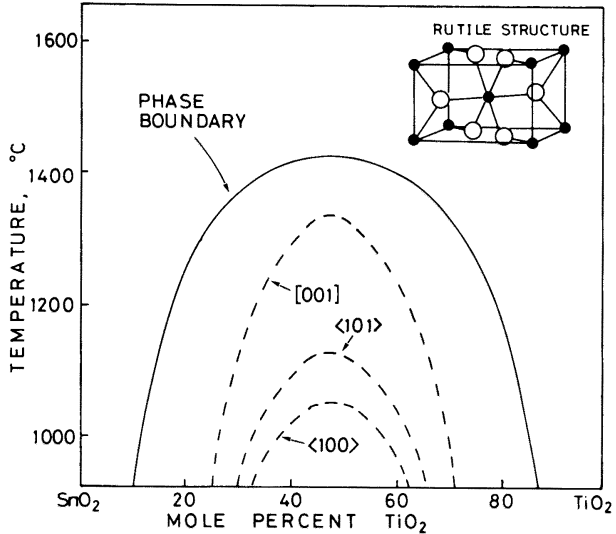

Fig. 5. Phase diagram of $\mathrm{SnO}_{2}-\mathrm{TiO}_{2}$ system. The coherent spinodals were calculated by PARK et $a .^{30)}$.

一方この系については熱処理に伴う組織変化の観察 がなされており，適当な組成の $\mathrm{SnO}_{2}-\mathrm{TiO}_{2}$ を 2 相領域 内で熱処理すると変調構造が形成されることが見出され ている ${ }^{33) ~-36)}$. この変調構造の縞模様が濃度変調によつ て生じているものとすると，その方向はスピノーダル分 解の理論から予想されるとおり [001] 方向になつてい る.また, 最近の研究により $\mathrm{SnO}_{2}-\mathrm{TiO}_{2}$ の濃度ゆらぎ が高分解能電子顕微鏡観祭によつて捕えられており ${ }^{36)}$, この系においてスピノーダル分解が起こることは一般に 受け入れられつつある. しかし，ガラスの研究における ように，相分離の初期過程に関する速度論的な検討はな されておらず，相分離機構の詳細な解析は今後の研究に 待たねばならない。酸化物セラミックスに関してはこの 他に $\mathrm{Al}_{2} \mathrm{O}_{3}-\mathrm{Cr}_{2} \mathrm{O}_{3}$ および $\mathrm{Al}_{2} \mathrm{O}_{3}-\mathrm{Cr}_{2} \mathrm{O}_{3}-\mathrm{Fe}_{2} \mathrm{O}_{3}{ }^{37)}$, $\mathrm{CoFe}_{2} \mathrm{O}_{4}-\mathrm{Co}_{3} \mathrm{O}_{4}{ }^{38)}$ についてスピノーダル分解の研究が なされている. しかし, 結晶質セラミックスのスピノー ダル分解の研究は, ガラスに比べるとはるかに不十分で ある。

\section{4. $\mathrm{ZrO}_{2}-\mathrm{Y}_{2} \mathrm{O}_{3}$ の立方晶/正方晶相分離}

高強度・高靱性セラミックスとして近年, 部分安定化 ジルコニア (PSZ) が注目を集めている.PSZの優れ た機械的特性は, マルテンサイト変態に起因しているこ とが明らかにされ，この材料について相変態特性と強鞀 化機構の関連性が盛んに研究されてきている39)-41). 筆 者らは, $\mathrm{Y}_{2} \mathrm{O}_{3}$ を添加したPSZ (Y-PSZ) の熱処理の 初期段階に特有の変調構造が形成されることを見出し, これがスピノーダル分解によつて生じた可能性の高いこ とを報告した ${ }^{42)-44)}$. この組織の発達が真にスピノーダ ル分解に起因しているか否かについては, 現在盛んに議 論されているところでありここの組織を生ずる相分離機 


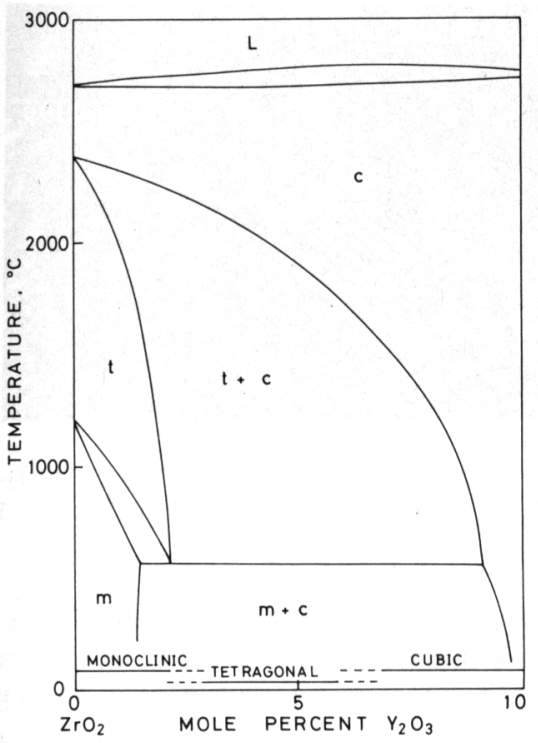

Fig. 6. Zirconia-rich part of $\mathrm{ZrO}_{2}-\mathrm{Y}_{2} \mathrm{O}_{3}$ system $^{45)}$.

構に関してはいまだ定説が確立されるには至つていな い.また, Y-PSZ の立方晶/正方晶 $(c / t)$ 相分離がス ピノーダル分解によつて起こつているものとすると、こ れは前章の結晶質セラミックスのスピノーダル分解の範 ちゆうに属するものであるが，この話題が最近のトピッ クスになつていること，筆者自身がこの問題に深くかか わりあつていることの理由で,ここでは新たに章を設け, やや詳しく紹介する.

Fig. 6 は ScotT による $\mathrm{ZrO}_{2}-\mathrm{Y}_{2} \mathrm{O}_{3}$ 系の $\mathrm{ZrO}_{2}$ に富 む領域の状態図である ${ }^{45)}$. この状態図は, PSZ の研究 者によりこれまで最もよく引用されてきたものである が, 最近の研究結果によると ${ }^{46) 47)}$, この状態図の高温 領域はかなりの修正が必要であると思われる。しかし， およそ $1800^{\circ} \mathrm{C}$ 以上の高温領域を除けば, Fig. 6 の状 態図を用いて $c / t 2$ 相分離を論じても差し支えないと いえる，Y-PSZ は，工業的には組成制御された原料粉 末を用いてホットプレスもしくは HIP 処理によつて製 造されるが，その焼結温度は多くの場合 $c / t 2$ 相領域 内にある。このため, 焼結と同時に 2 相分離が起こるこ とになる。したがつて, 焼結体の微細組織は粉末の製造 条件, 焼結条件によつて複雑に変化し, その組織の理解 は必ずしも容易ではない。 そこで, Y-PSZ の微細組織 の理解を容易にするために，ここではまず高温から急速 に冷却した試料の組織を示す.

Photo. 2 は, 3 種類の $\mathrm{ZrO}_{2}-\mathrm{Y}_{2} \mathrm{O}_{3}$ の組織である ${ }^{48)}$. 試料はいずれも溶解後水冷銅鋳型上で放冷されたもので あり，融点から $1000^{\circ} \mathrm{C}$ までおよそ $10 \mathrm{~s} て ゙$ 冷却されて いる. Photo. 2 (a) は純 $\mathrm{ZrO}_{2}$ の組織であり, 双晶を含

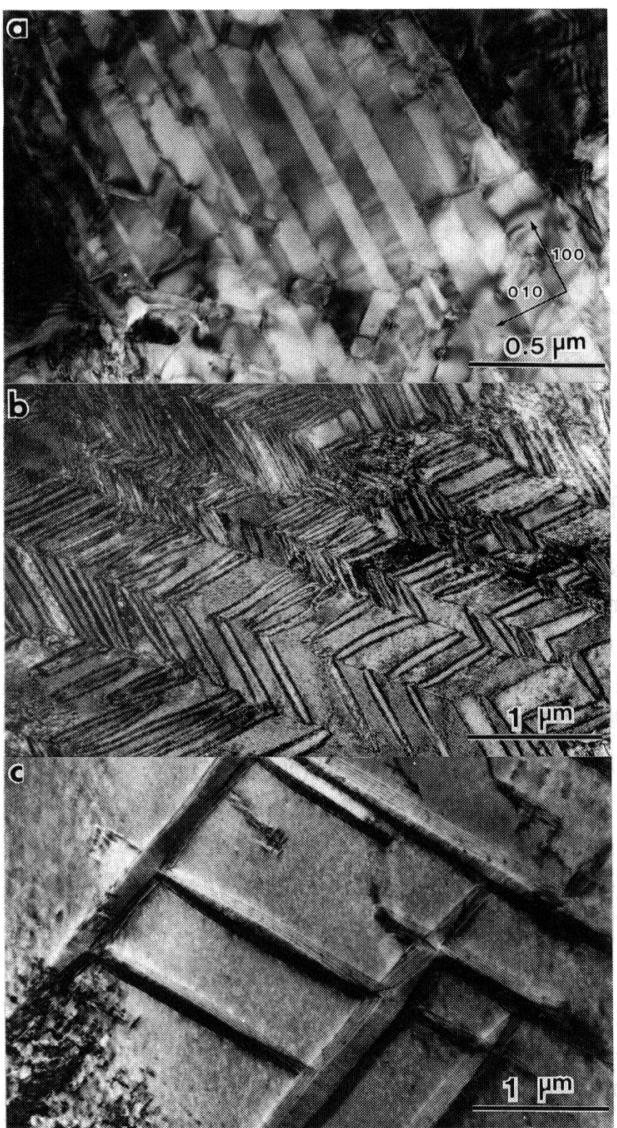

Photo. 2. Microstructures of arc-melted (a): $\mathrm{ZrO}_{2} \quad$ (b) : $\mathrm{ZrO}_{2}-3$ mol\% $\mathrm{Y}_{2} \mathrm{O}_{3} \quad$ (c) $: \mathrm{ZrO}_{2}-5$ mol $\% \mathrm{Y}_{2} \mathrm{O}_{3}$ alloys ${ }^{42) 48)}$ (by courtesy of Chapman and Hall Ltd.).

んだ単斜晶相 $\left(m-\mathrm{ZrO}_{2}\right)$ である。この組織は比較的以 前から研究されているものであり, 双晶面は $\{100\}$ あ るいは $\{110\}$ 面であることが明らかにされてい る 49)50). Photo. 2(b) は $\mathrm{ZrO}_{2}-3 \mathrm{~mol} \% \mathrm{Y}_{2} \mathrm{O}_{3}$ の組織であ り，特徴的な微細組織を有している ${ }^{51)}$. この組織を有 する相の結晶構造については現在盛んに議論がなされて いる. $\mathrm{Y}_{2} \mathrm{O}_{3}$ 濃度がさらに高くなり，拈よそ 4 7 $\mathrm{mol} \%$ の試料には Photo. 2 (c) のような組織が現れる.これ は, マトリックス中にレンズ状の正方晶相 $\left(t^{\prime}-\mathrm{ZrO}_{2}\right)^{\dagger}$ が存在する組織であり，金属材料にみられるレンズ状マ ルテンサイトと似た形態を有している，その組織の類似 性から, 当初マトリックスが残留立方晶相 $\left(c-\mathrm{ZrO}_{2}\right)$, レンズ状の相が高温からの急冷に際してマルテンサイト

$† \mathrm{Y}_{2} \mathrm{O}_{3}$ 濃度の高い正方晶相は安定であり, 容易に $m-\mathrm{ZrO}_{2}$ に変態しな い.このような正方晶相を $t^{\prime}-\mathrm{ZrO}_{2}$ とよび, 通常の低 $\mathrm{Y}_{2} \mathrm{O}_{3}$ の正方 晶相 $\left(t-\mathrm{ZrO}_{2}\right)$ と区別しようという提案がなされれ ${ }^{52 / 53)}$ ，かなり広く 受け入れられている。 


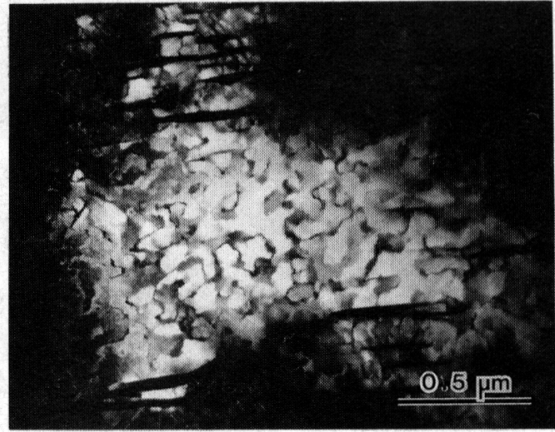

Photo. 3. Domain structure of $\mathrm{ZrO}_{2}-4$ mol\% $\mathrm{Y}_{2} \mathrm{O}_{3}$ alloy. The micrograph was taken by a 112 reflection, which is forbidden for cubic fluorite structure ${ }^{56)}$.

変態によつて形成された $t^{\prime}$ 相という解釈がなされ た ${ }^{48) 54)}$.この解釈が妥当であるとすると, Photo. 2 (c) の組織は Partially-transformed structure と見なすこと ができる.ところがその後, Photo. 2(c) のマトリック スからも螢石型立方晶構造では禁制となる 112 タイプ の反射が現れることが明らかにされ ${ }^{55)}$ ，この組織に対 する理解の再検討がせまられている。この禁制反射を用 いた暗視野像には, Photo. 3 のような特有のドメイン 構造が現れる ${ }^{56)}$.このドメイン構造は, 溶解材, 焼結 体を問わずかなり広い組成範囲にわたつて見られ

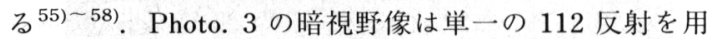
いて撮影されたものであり，単一のバリアントの $t^{\prime}-\mathrm{ZrO}_{2}$ がこのようなドメイン構造を有しているのであ る.ドメインの境界は規則合金にみられる逆位相境界に 類似したコントラストを示している.このドメイン構造 に関しては完全な解釈がなされているわけではないが,

隣接するドメインは同一の $c$ 軸を有し, $\mathrm{O}^{2-}$ イオンが

[001] 軸のまわりに $90^{\circ}$ 回転した配列になつていると いう考え方が支配的である ${ }^{55)}$.このように，Y-PSZの 微細組織は $\mathrm{Y}_{2} \mathrm{O}_{3}$ 濃度によつて顕著に変化し, しかも高 温から急冷した組織の成因自体がいまだ十分に理解され ていないので, 熱処理に伴う組織変化に関しても未解決 の問題が山積みしている。ここでは本稿の題目に即する ように, $c / t 2$ 相領域での時効の初期に現れる変調構造 について述べることにする.

Photo. 4 は, $\mathrm{ZrO}_{2}-4 \mathrm{~mol} \% \mathrm{Y}_{2} \mathrm{O}_{3}$ を $1700^{\circ} \mathrm{C}$ で 10 $\min$ 時効した試料について得られた微細組織である ${ }^{44)}$. この組織は, PSZ に見られる通常の析出組織 59 ) 62) と は明らかに異なつている。この変調構造の白黒の縞模様 に垂直な方向は, $c-\mathrm{ZrO}_{2}$ の<111>方向にほぼ平行に なっており，この方向にサイドバンドが現れる ${ }^{44)}$. $c-\mathrm{ZrO}_{2}$ の弾性定数の測定結果によれば63), この<111 $>$ 方向は弾性的に軟らかい方向になつている。また，変

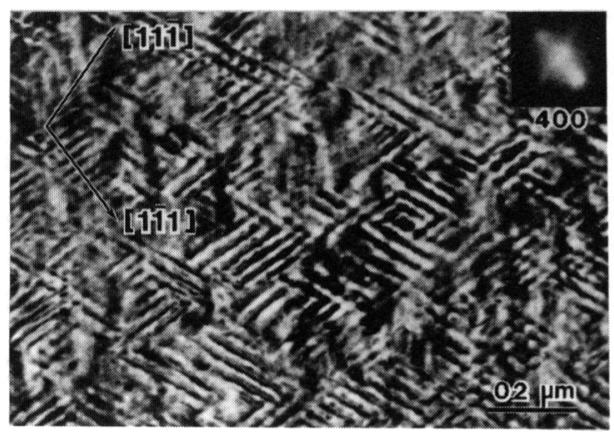

Photo. 4. Microstructure formed in $\mathrm{ZrO}_{2}-4$ mol\% $\mathrm{Y}_{2} \mathrm{O}_{3}$ isothermally-aged at $1700^{\circ} \mathrm{C}$ for 10 $\min ^{44)}$.

調構造は等温時効の初期段階に現れ，時効時間が長くな ると通常の析出組織に変わつていくことが確かめられて いる ${ }^{42)}$.これらの事実は, $\mathrm{SnO}_{2}-\mathrm{TiO}_{2}$ と同様に Y-PSZ の変調構造がスピノーダル分解と関連している ことを示唆しているように思われる。これに反して，焼 結体の熱処理過程で類似の組織が形成されることを見出 している研究者は,これをツイード組織と呼んでおり, この組織が母相中に微細に分散した整合な析出粒子によ るひずみ場コントラストであると解釈している ${ }^{55)}$. 変 調構造とツイード組織の区別は実験的に容易ではなく, この組織の解釈には今後さらに議論が続けられるであろ j.

ところで，Y-PSZ にスピノーダル分解が起こるとす ると,これはどのような相分離であろうか. $\mathrm{ZrO}_{2}-\mathrm{Y}_{2} \mathrm{O}_{3}$ の $\mathrm{ZrO}_{2}$ に富む領域が Fig. 6 のような状態 図を有しているものとすると, この領域に準安定の 2 相 分離が存在していることが予想される。変調構造は常に $t-\mathrm{ZrO}_{2}$ (もしくは $\left.t^{\prime}-\mathrm{ZrO}_{2}\right)$ が関与していることが明 らかにされており ${ }^{44)}$ ，このような準安定の相分離とし ては $t-\mathrm{ZrO}_{2}$ の 2 相分離が考えられる。この 2 相分離 の可能性もあるが, ここでは $c / t$ 相分離が極めて特異 な性格を有するものであり, $c / t$ 相分離がスピノーダル 分解によつて起こる可能性があることを指摘しておきた い.

Fig. 7 は, $c / t 2$ 相平衡に関する最近の研究結果をま とめて示したものである．Fig. 6 に示した ScoTT の状 態図は, Fig. 7 に白丸で示されているデータから得ら れたものであり，数種の $\mathrm{ZrO}_{2}-\mathrm{Y}_{2} \mathrm{O}_{3}$ について室温にお けるX 線解析の結果から高温相を推定しているため ${ }^{45)}$, とくに高温におけるデータの信頼性は高いとは言い難 い. Fig. 7 の他の研究者の結果は, いずれも平衡化の 熱処理後分析によつて得られた值である.このデー夕に よると, 高温領域では $c / t 2$ 相領域が ScOTT によつて 報告されているものよりもかなり狭くなつており, $c / t$ 


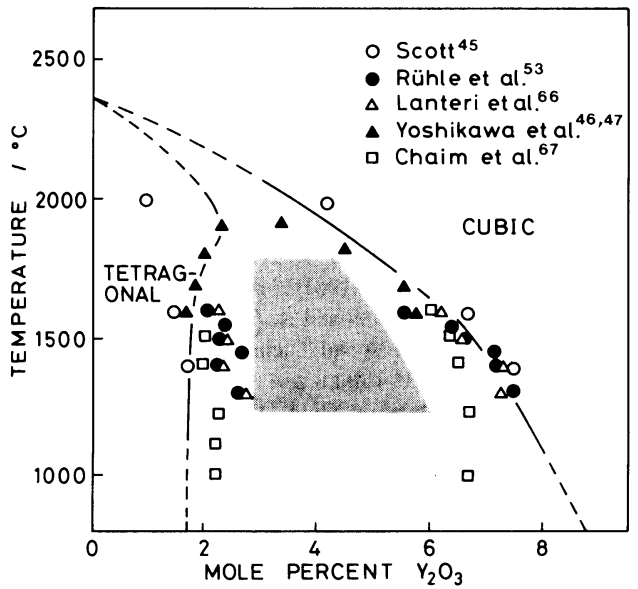

Fig. 7. Cubic-tetragonal two phase region in $\mathrm{ZrO}_{2}-\mathrm{Y}_{2} \mathrm{O}_{3}$. Hatched area snows the region where the modulated structure is developed by aging ${ }^{44)}$.

2 相領域は特徵的な形を有していることが知られる。 た，変調構造が見られる領域は Fig. 7 にハッチングで 示したように $c / t 2$ 相領域の内側に存在している ${ }^{44)}$.

このような $c / t 2$ 相領域の特徽と関連して, $c-t$ 相変 態が 2 次变態の性格を有していることが知られてきてい る. その第 1 は, 高温からの冷却に際して生じる Y-PSZ の $c \rightarrow t$ 変態は, 冷却速度によらず常に試料全 面にわたつて完了し, その結果 Photo. 3. のようなドメ イン構造を生じるということである ${ }^{56) 64)}$.この $c-t$ 変態 の特性は規則一不規則変態と似ており，変態によつて形 成されるドメイン境界は逆位相境界と似たコントラスト を有している，また，純粋なジルコニアの $t-\mathrm{ZrO}_{2}$ の軸 比 $c / a$ は抢よそ $2000^{\circ} \mathrm{C}$ 付近で温度の上昇につれて急 激に減少し, $c-\mathrm{ZrO}_{2}$ の格子定数に連続的に変化してい くようみえる ${ }^{65)}$. 同様の傾问は $t-\mathrm{ZrO}_{2}$ (もしくは $t^{\prime}$ $\left.-\mathrm{ZrO}_{2}\right)$ の $c / a$ の $\mathrm{Y}_{2} \mathrm{O}_{3}$ 濃度による变化にもみられる. すなわち, $c / a$ は $\mathrm{Y}_{2} \mathrm{O}_{3}$ 濃度の増加と共に連続的に減少 し, 約 $9 \mathrm{~mol} \% \mathrm{Y}_{2} \mathrm{O}_{3}$ で $c / a$ が 1 となり, $c-\mathrm{ZrO}_{2}$ の格 子定数に極めて近い值をとる ${ }^{45)}$.これらの特徵はいず れも $c-t$ 変態が 2 次変態の特徽を有することを示してい る.このような結果から判断すると, 拡散が関与する $c-t$ 相分離がスピノーダル分解によつて起こることもあ りうるように思われる。いずれにしても，Y-PSZの $c-t$ 相変態および相分離は極めて特異な性格を有してい ることは確かである。しかし，この事実が認識されてい まだ日が浅く，その挙動の解明は與味深い課題として今 後に残されている。

\section{5.お わりに}

「セラミックスのスピノーダル分解」という魅力的な 題目の解説原稿を依頼され，その題目にひかれて筆を執 つたしだいであるが，このように大きな主題を限られた 紙数で紹介することは筆者の力に余るものであり，記述 が表面的になつたことをお許しいただきたい。また，七 ラミックスのスピノーダル分解の研究レベルは分野によ つて大きく異なつており，各章の記述が首尾一貫したも のとならなかつた.この点に関しては読者諸賢の御批判, 御教示をいただければ幸いである。 スピノーダル分解を はじめとするセラミックスの相変態の研究は, 金属材料 に比べて遅れているところが多い. 今後この種の研究が 盛んとなり，PSZ のような相変態を利用したセラミッ ク材料が開発されることを期待したい. なお，ガラスの スピノーダル分解に関する文献検索では新日本製鉄 (株) 第一技術研究所 久保紘主任研究員, $\mathrm{TiC}-\mathrm{Ni}$ サーメッ トについては東京大学工学部金属材料学科 松原秀彰氏 の協力を得た。記して感謝の意を表する.

\section{文献}

1 ) J. ZARZYCKI: Discuss. Faraday Soc., 50 (1970), p. 122

2) J. E. Hilliard: Phase Transformations, ASM (1970), p. 497

3 ) J. S. Langer: Ann. Phys., 65 (1971), p. 53

4 ) R. J. Charles: Bull. Am. Ceram. Soc., 52 (1973), p. 673

5 ) 友沢 稔: 材料科学, 11 (1974), p. 298

6 ) P. F. JamEs: J. Mater. Sci., 10 (1975), p. 1802

7 ) D. R. Uhlman and A. G. Kolbeck: Phys. Chem. Glasses, 17 (1976), p. 146

8 ）横田良助: 窯業協会誌, 86 (1978), p. 7

9 ）境野照雄: 表面, 16 (1978), p. 591

10) $M$. Tomozawa: Treatise on Materials Science and Technology, ed. by $M$. Tomozawa and $R$. H. Doremus, 17 (1978), p. 71 [Academic Press]

11) C. M. F. JANTZEN and H. HERMAN: Refract. Mater., 6 (1978), p. 127

12) A. F. Craievich, E. E. Zanotto and P. F. James: Bull. Minéral, 106 (1983), p. 169

13） W. D. Kingery, H. K. Bowen and D. R. Uhlman 著，小松 和蔵ら訳: セラミックスの材料科学入門，基礎編 (1980), p. 106 [内田老鶴圃新社]

14) T. R. Rockett and W. R. Foster: J. Am. Ceram. Soc., 47 (1964), p. 559

15) R. MCPherson and B. V. Shafer: J. Mater. Sci., 19 (1984), p. 2696

16) J. W. CAHN: Acta Metall., 9 (1961), p. 795, 10 (1962), p. 179

17) M. Hillert: Acta Metall, 9 (1961), p. 525

18) J. W. Cahn and $R$. Charles: Phys. Chem. Glasses, 6 (1965), p, 181

19) J. ZARZYCKI and $F$. NAUDin: J. Non-crystalline Solids, 1 (1969), p. 215

20) A. Craievich: Phys. Chem. Glasses, 16 (1975), p. 133

21) G. F. Neilson: Phys. Chem. Glasses, 10 (1969), p. 54

22) R. J. Stokes and C. H. Li: Acta Metall., 10 (1962), p. 535 
23) $R$. Kieffer, $G$. Trabesinger and $N$. Reiter: Planseeberichte für Pulvermetallurgie, 17 (1969), p. 25

24) E. Rudy: $J$. Less-Common Metals, 33 (1973), p. 43

25) P. Murray and J. E. Weston: J. Less-Common Metals, 81 (1981), p. 173

26）鈴木 寿, 林 宏爾, 松原秀彰: 日本金属学会会報, 22 (1983), p. 312

27) D. Moskowitz and M. HumEniK, Jr.: Modern Developments in Powder Metallurgy, ed. by H. H. Hausner, 3 (1966), p. 83 [Plenum Press, New York]

28) $R$. KiefFer, $P$. EtTMayer and $M$. Freudhofmeier: Modern Developments in Powder Metallurgy, ed. by $H$. $H$. HANSNER, 5 (1971), p. 201 [Plenum Press, New York]

29）鈴木 寿: 日本金属学会分科会シンポジウム, 耐熱構造用 セラミックスの製法, 組織扔よび特性 (1984), p. 25

30) M. Park, T. E. Mitchell and A. H. Heuer: J. Am. Ceram. Soc., 58 (1975), p. 43

31) N. N. Padurow: Naturwissenschaften, 43 (1956), p. 395

32) D. Garcia and D. Speidel: J. Am. Ceram. Soc., 55 (1972), p. 322

33) A. H. Schultz and V. S. Stubican: Phil. Mag., 18 (1968), p. 929

34) P. K. Gupta and A. R. Cooper: Phil. Mag., 21 (1970), p. 611

35) V. S. Stubican and A. H. Schultz: J. Am. Ceram. Soc., 53 (1970), p. 211

36) S. Horiuchi, $F$. Izumi, T. KikUChi and $K$. Uchida: Phil. Mag., A50 (1984), L29

37) A. H. Schultz and V. S. Stubican: J. Am. Ceram. Soc., 53 (1970), p. 613

38) M. Takahashi, J. $R$. C. Guimaräes and $M$. E. Fine: J. Am. Ceram. Soc., 54 (1971), p. 291

39）小林啓佑，正木孝樹: セラミックス, 17 (1982), p. 427

40）須藤 一, 佐久間健人: 日本金属学会会報, 22 (1983), p. 887

41) 佐藤次雄, 島田昌彦: セラミックス, 21 (1986), p. 613

42) T. Sakuma, $Y$. Yoshizawa and $H$. Suto: J. Mater. Sci., 20 (1985), p. 1085

43）佐久間健人: ジルコニアセラミックス, 6 (1986), p. 9

44) T. Sakuma, Y. Yoshizawa and $H$. Suto: J. Mater. Sci., $21 \cdot(1986)$, p. 1436

45) H. G. ScotT: J. Mater. Sci., 10 (1975), p. 1527

46）吉川 昇, 江田浩之, 須藤 一: 日本金属学会誌, 50 (1986), p. 113

47）吉川 昇, 須藤 一: 日本金属学会誌, 50 (1986), p. 1101

48) T. Sakuma, $Y$. Yoshizawa and $H$. Suto: J. Mater. Sci., 20
(1985), p. 2399

49) J. E. Bailey: Proc. Roy. Soc., 279A (1964), p. 359

50) G. K. Bausal and A. H. Heuer: Acta Metall., 20 (1972), p. 1281

51) T. Sakuma, $Y$. Yoshizawa and $H$. Suto: J. Mater. Sci. Lett., 4 (1985), p. 29

52) R. A. Miller, J. L. SmialeK and R. G. Garlick: Advances in Ceramics, 3, Science and Technology of Zirconia, ed. by $A$. $H$. Heuer and $L$. W. HoBbs, The Am. Ceram. Soc., Columbus, Ohio (1981), p. 241

53) $M$. Rühle, $N$. Claussen and $A$. $H$. Heuer: Advances in Ceramics, 12, Science and Technology of Zirconia II, ed. by $N$. Claussen, $M$. Rühle and $A$. $H$. Heuer, The Am. Ceram. Soc., Columbus, Ohio (1984), p. 352

54) C. A. Andersson and T. K. GuPTA: Advances in Ceramics, 3. Science and Technolngy of Zirconia, ed. by $A$. $H$. Heuer and $L$. $W$. HobBs, The Am. Ceram. Soc., Columbus, Ohio (1981), p. 184

55) $R$. Chaim, $M$. Rühle and $A$. $H$. Heuer: J. Am. Ceram. Soc., 68 (1985), p. 427

56) $T$. Sakuma and $H$. Suto: The 3 rd Iutul. Cont. on the Science and Technology of Zirconia, Tokyo (1986), Extended Abstracts p. 346

57） M. SugiYamA and $H$. KuBo: 害業協会誌，94（1986）, p. 726

58) B. A. Bender, R. P. Ingel, W. J. McDonough and J. $R$. SpanN: Adv. Ceram. Mater., 1 (1986), p. 137

59) D. L. Porter and A. H. Heuer: J. Am. Ceram. Soc., 60 (1977), p. 183

60) R. H. J. HanninK: J. Mater. Sci., 13 (1978), p. 2487

61) D. L. Porter and A. H. Heuer: J. Am. Ceram. Soc., 62 (1979), p. 298

62）浦部和順, 野間竜男, 佐伯 淳, 吉村昌弘, 宗宮重行: ジルコニアセラミックス, 8 (1986), p. 45

63) H. M. Kandil, J. D. GReiner and J. F. Smith: J. Am. Ceram. Soc., 67 (1984), p. 341

64) $V$. Lanteri, $R$. Chaim and $A$. $H$. Heuer: J. Am. Ceram Soc., 69 (1986), c-258

65) P. Aldebertand $J$ - $P$. Traverse: J. Am. Ceram. Soc., 68 (1985), p. 34

66) $V$. Lanteri, $A . H$. Heuer and $T$. E. Mitchell: Advances in Ceramics, 12, Science and Technology of Zirconia II, ed. by $N$. Claussen, $M$. Rühle and $A$. $H$. Heuer, The Am. Ceram. Soc., Columbus, Ohio (1984), p. 118

67) R. Chaim, $A . H$. Heuer and $D$. G. Brandon: J. Am. Ceram. Soc., 69 (1986), p. 243 